\title{
Beyond Internalization: Alternate Endings of the Norm Life Cycle
}

\author{
Theory Note \\ Anette Stimmer, University of Oxford
}

\begin{abstract}
Norm scholars tend to treat norm contestation and acceptance as binary categories. This obscures variation in how much states agree over how to apply international law to specific situations. I distinguish between disagreements over norm frames (justifications) and claims (actions), and thus highlight four different outcomes of norm contestation. These differ in their effects on the clarity and strength of the contested norms, as well as on subsequent debate over them. Specifically, I argue that frame agreement limits the range of actions that actors can legitimately pursue, and thus involves norm recognition. In contrast, if states only agree on the action that should be taken, but not on the norm that applies, we see norm neglect. Both outcomes structure subsequent debates, but norm neglect is the more volatile outcome: because of the lack of normative commitment, states can justify the agreed-upon action as exceptional compromise and later revert back to a norm impasse (frame and claim disagreement). However, the joint action may also trigger socialization processes that lead to agreement on both frames and claims — that is, produce norm clarification. Hence, this typology builds a bridge between understandings of contestation as a never-ending debate and as an avenue towards agreement; it helps improve our understanding of compliance mechanisms and of contestation.
\end{abstract}

Acknowledgements: I thank lan Johnstone, Nicole De Silva and especially, Duncan Snidal, three anonymous reviewers and the ISQ editorial team for their many helpful comments.

Edmund Downie, Diana Hackett and Lea Wisken provided valuable assistance in editing the manuscript. Earlier versions also benefited from feedback at the 2017 International Studies Association and British International Studies Association Annual Conventions.

\section{Introduction}

The first wave of scholars that emphasized the role of norms in international affairs often treated their meaning as clear and stable (Finnemore and Sikkink 1998, 904). Doing so made it easier to demonstrate their influence on the behavior of states. However, a growing number of scholars focus on the ambiguous character of norms and how their overlap generates tensions and inconsistencies. Both of these features make norms the subject of debate and contestation. ${ }^{1}$

Those studying norm change and contestation agree that their meaning is dynamic and shaped by debate. However, their scholarly agendas differ. One group of scholars analyze how disputes

\footnotetext{
1 See, for example, Acharya (2004; 2011; 2013); Bloomfield (2016); Bower (2015); Evers (2017); Krook and True (2012); Mills and Bloomfield (2018); Niemann and Schillinger (2017); Panke and Petersohn (2016); Sandholtz (2008); Wiener (2004; 2008; 2014); Wolff and Zimmermann (2016); Zimmermann (2017); Zwingel (2012).
} 
generate new shared understandings at the international (Bower 2015, 348-58; Sandholtz 2008, 110-21) or regional level (Schimmelfennig 2001, 66-76), or trace modifications during the diffusion process (Acharya 2004, 250-54; Krook and True 2012, 109-11). Another studies the implications of disagreement over norms: some believe that contestation can take the form of ongoing and inclusive dialogue that makes norms more legitimate (Wiener 2014, 3), whereas others are skeptical that actors can share an understanding of the meaning and implications of norms (Niemann and Schillinger 2017, 48). However, little scholarship systematically explores different kinds of agreements and disagreements over the meaning of norms and how these variations in disagreements influence state behavior.

In this note, I develop a theoretical framework that allows us to capture alternate endings of norm contestation; it refines the idea of the 'dual quality' of norms-as both stable and dynamic, structuring and constructed (Wiener 2008, 38). Drawing on theories of political rhetoric (Krebs and Jackson 2007; Toulmin 1958), I show that breaking norms down into norm frames (justifications) and claims (to action) allows us to categorize agreements and disagreements over them. The elements that states agree or disagree on affect the precision of norms in different ways; they have distinct implications for a norm's ability to influence state behavior.

Contestation over norm application can end in four different ways.

We see norm clarification when contestants agree on the norm frame and claim. Consider the agreement after 9/11 on a right to self-defense against state-sponsored terrorism (frame), and intervention in Afghanistan (claim). Such norm clarification increases normative guidance and social pressure to conform in similar situations in the future.

Sometimes contestants only agree on the norm frame but not on the concrete action, since a range of actions may fall under the frame. The normative agreement still provides a reference point, albeit a weaker one than norm clarification. Norm recognition is a stable outcome, so long as the disagreement on the claim does not blatantly contradict the frame.

In contrast, disagreement on both the frame and the claim decreases normative certainty and cooperation. Consider the dispute over whether Crimeans' right to self-determination or Ukraine's sovereignty prevails (frames), and which country Crimea belongs to (claims). I argue that whether 
such a norm impasse is sustainable depends on the nature and extent of previously shared commitments.

Lastly, frame disagreement coupled with claim agreement leads to joint actions, and may thus seem like norm clarification. The no-fly zone over Libya (claim), for which Security Council members provided different justifications, is sometimes mistakenly viewed as clarifying the responsibility to protect $(\mathrm{R} 2 \mathrm{P})$. However, such norm neglect is a volatile outcome: due to the lack of consensus on a norm frame, states can justify a prior claim agreement as an exceptional compromise in a norm impasse. The joint action may also trigger socialization processes that lead to norm clarification. Further, I argue that whether contestation strengthens or weakens norms also depends on whether it expands or narrows the norm's scope, as well as the outcome that preceded it.

This note proceeds as follows. First, I discuss how scholarly analysis of either the resolution or the persistence of norm contestation divides the literature. I suggest moving away from these absolutes to explore the effect of contestation on norm precision and influence. Second, I describe four configurations of norm frames and claims, and the implications of each configuration for the clarity and strength of the contested norm(s) and subsequent debate. Third, I provide an extended illustration of the dynamics of norm contestation. I conclude by explaining why mapping norm contestation outcomes matters, and by discussing how this typology can help refine the mechanisms scholars consider to curb or fuel contestation.

\section{Conceptualization of norms and norm contestation}

The first wave of norm scholars argue that norms matter in an anarchical international environment and explain how they affect state behavior. In so doing, scholars often treated the meaning of norms as relatively static and clear. For instance, Finnemore and Sikkink $(1998,897)$ acknowledge contestation in the early stages of the norm 'life cycle'. However, they $(1998,895)$ argue that norm evolution culminates in internalization, meaning that "norms acquire a taken-forgranted quality and are no longer a matter of broad public debate". Their theory cannot explain continuing debates about such established legal norms as the prohibition of torture (Keating 2014) or the subsidiarity principle in the European Union (Van Kersbergen and Verbeek 2007). The same holds for two other prominent constructivist theories on norm diffusion and compliance: the 
'boomerang' (Keck and Sikkink 1998) and 'spiral' models (Risse and Sikkink 1999). These models do not sufficiently explore conflicting interpretations and subtler changes in meaning of established norms. Rational choice accounts that use criminalization of outlawed behavior as indicators of compliance also neglect disputes over legal interpretation (Kelley and Simmons 2015, 62).

A second wave of norm scholars argue that contestation can happen at any point in the norm life cycle. Treaty drafters cannot foresee every possible contingency. Linguistic ambiguities and overlapping norms also reduce interpretive clarity (Krook and True 2012, 109; Sandholtz 2008, 105-06). Norm contestation is possible whenever actors apply a general rule to a specific situation, and such application may change or alter the rule. Norm application can provoke debates over the meaning of a particular norm, or over the relative importance of different norms. Second-wave scholars primarily focus on international legal norms and consider norm contestation to involve disputes about the meaning, validity, or application of norms (Wolff and Zimmermann 2016, 518).

Scholars generally define a norm as "a standard of appropriate behavior for actors with a given identity" (Finnemore and Sikkink 1998, 891). Norms elicit feelings of obligation (Abbott et al. 2000, 408-12; Finnemore and Toope 2001, 744). They are intersubjective constructs and provide reference points for what actions others consider acceptable. The clarity of these reference points can vary where actors' norm understandings diverge. These variations affect future debates, actions and the status of norms. Wiener refers to these variations as the "dual quality of norms as structuring and constructed" (Wiener 2004, 191). Debates over norms construct the meaning of norms, and enable or constrain future episodes of norm contestation. The existing literature neglects variations in outcomes beyond disagreement or agreement, and thus fails to fully explore how the meaning of norms is both constructed by actors, and structures their actions.

The recognition of dynamic meaning led to research on how norms change during the diffusion process and helped overcome the Western bias of much of the earlier literature. Local or weaker actors actively participate in norm change. Research on 'localization', 'subsidiarity' or 'circulation' of the meaning of norms (Acharya 2004, 244-246; 2011 97-99; 2013, 469-471) and on multidirectional processes of norm 'translation' (Zimmermann 2017, 775-777; Zwingel 2012, 124-126) provides many examples. Hence, some scholars consider the inherent contestability of norms as a positive quality because diverse voices become heard. Wiener $(2004,218 ; 2014,5)$ 
and Acharya $(2004,252-53 ; 2011,116-17 ; 2013$, 471) do not see contestation as indicating the irrelevance of norms, but as an opportunity to uncover different normative understandings which can enhance the social legitimacy of norms. ${ }^{2}$ These scholars imagine contestation as an ongoing dialogue. Hence, they do not thoroughly explore how variations in understandings affect the contested norms or structure subsequent debates.

Not all critical constructivists view the potential of contestation to increase legitimacy with such optimism. Some consider discourses and debates over norms such as the anti-whaling norm (Epstein 2008), as "generative structures that are always charged with relations of domination" (Epstein 2013, 502). This strand of the literature explores the ways in which contestation reflects or reproduces pre-existing biases, identity categories, and power relationships. These scholars focus less on the meaning of norms and more on the role that norm contestation plays in creating identity categories of actors, and on the way that relationships structure contestation (Epstein 2008, 22; Evers 2017, 786). Some consider the meaning of norms as contested "all the way down" (Niemann and Schillinger 2017, 48).

The malleability of norms makes some scholars question the relevance of international law (Koskenniemi 2005, 61). If norms have no fixed meaning, powerful states can manipulate norms to legitimize their preferences and influence the behavior of others (Brooks and Wohlforth 2005, 518; Byers 2003, 173; Ikenberry and Kupchan 1990, 283). However, since norms are not subjective but intersubjective, such strategic applications face an important social limit: the need to gain acceptance from others. An influential strand of the literature explores structural constraints on norm interpretations. Some scholars cite the need for actors to portray competence in negotiations over the meaning of norms (Adler-Nissen and Pouliot 2014, 893-96). Others refer to conventions of legal argumentation (Bower 2015, 339; Johnstone 2011, 21-27; Sandholtz 2008, 106-110), the power of the status quo (Bloomfield 2016, 312), the network position of an actor (Goddard 2006, 40), or public expectations that prior commitments should be honored (Schimmelfennig 2001, 66). These scholars uncover social or normative limitations on state behavior. They focus on how actors could stop powerful states' attempts at manipulation and generate legitimate norm interpretations: but norm contestation does not always end in agreement.

\footnotetext{
2 For a more detailed discussion of Acharya's and Wiener's view of contestation as "a good thing" (p. 527), see Wolff and Zimmermann (2016).
} 
To summarize, critical scholars tend to conceptualize norm contestation either as an ongoing dialogue reflecting diversity or as merely another arena of power relations. The latter assumption prompted research into how social expectations generate agreement on the meaning of norms and limit opportunism to show that norms can guide state behavior. I propose to move beyond a dichotomous understanding of norm contestation and acceptance. A more nuanced account of agreements and disagreements on the meaning of norms helps us to grasp how contestation shapes norms and affects their influence on state behavior. Identifying alternate outcomes of norm contestation also allows us to better understand the effectiveness of structural constraints on strategic norm interpretations.

\section{Breaking Down Disagreements: The Role of Frames and Claims}

Rhetoric scholars (Krebs and Jackson 2007, 43; Schimmelfennig 2001, 73) distinguish two aspects of an argument: a "frame" or "warrant" providing a justification for the "claim" or "implication", describing an action that follows from it. Since the exchange of arguments reveals understandings of norms, we can also theorize norms as consisting of a frame and a claim. In law, this is essentially the difference between the rule (frame) and its application to a case that gives rise to a claim to action. For example, state A could argue that due to the prohibition of torture (frame), state B should be denounced for its actions that amount to torture (claim). Other states may subsequently agree or disagree with the frame, claim, or both.

Krebs and Jackson (2007) and Schimmelfennig (2008) draw on Toulmin when differentiating between frames and claims. Toulmin (1958) analyzes the structure of arguments and what elements make them persuasive. The three most basic elements of an argument are claims, warrants, and grounds (factual data) (Schimmelfennig 2008, 200; Toulmin 1958, 99-100). A warrant justifies the claim and explains why the grounds support the claim. I refer to warrants as frames because this concept captures their function in norm contestation well.

Following Goffman $(1974,21)$, scholars generally define frames as interpretive tools that allow actors "to locate, perceive, identify, and label" occurrences. Frames help to classify events, thereby rendering them meaningful and limiting the range of acceptable actions (Entman 1993, 54; Lenz 2018, 44; McAdam, Tarrow, and Tilly 2001, 30; Snow, Rochford Jr, Worden and Benford $1986,464)$. In the context of norms, norm frames offer standards for assessing whether actions 
are appropriate. They signal normative commitment and provide actions with a justification. Whether we frame a declaration of independence as an exercise of the right to self-determination or a violation of state sovereignty will determine what actions are considered appropriate. Actors can use frames to highlight some aspects of reality while obscuring others, so as to win support for their interpretation (Entman 1993, 54). In this sense, the framing of events is a strategic practice that may prompt contestation. As Schön and Rein $(1994,35)$ observe, a course of action may be compatible with different frames, and one frame may be consistent with several courses of action. Distinguishing between frames and claims to action lets us capture these different forms of disagreement. Furthermore, seeing claims and frames as the constituent parts of norms resembles the common understanding of customary law as the combination of state practice with expressions of belief of a legal obligation (opinio juris).

Building on Krebs and Jackson's $(2007,43)$ typology of argumentation outcomes, I propose four outcomes of norm contestation (shown in Table 1), depending on what actors disagree about: 1) norm clarification (agreement on frame and claim); 2) norm recognition (frame agreement, claim disagreement); 3) norm neglect (frame disagreement, claim agreement) and 4) norm impasse (disagreement on frame and claim).

Table 1: Overview of Norm Contestation Outcomes

\begin{tabular}{r|l|l} 
& Frame Agreement & Frame Disagreement \\
\hline Claim Agreement & Norm Clarification & Norm Neglect \\
\hline Claim Disagreement & Norm Recognition & Norm Impasse \\
\hline
\end{tabular}

Krebs and Jackson (2007) focus on agreements and disagreements over frames and claims in policy debates. In episodes of norm contestation, unlike in policy debates, it is not claim agreement but frame agreement and the associated normative commitment that provides stability. Before discussing this outcome typology, I will briefly explain whose norm interpretations matter and what constitutes agreement and disagreement.

International law can develop along many dimensions. I focus on the clarification of the meaning of norms. Widespread state consent tends to be necessary for international law to develop further (Bederman 2006, 34-35). Hence, state reactions to a norm interpretation have the most direct effect on legal norms, whether hard or soft. Finnemore and Sikkink $(1998,901)$ consider state 
consent as widespread enough when a tipping point of one third of states is reached, including "critical states (...) without which the achievement of the substantive norm goal is compromised". In norm contestation, actors are critical to the achievement of the substantive norm goal when their institutional position gives weight to their norm interpretations (Barnett and Duvall 2005, 5152; Busby 2007, 254; Goddard 2006, 40). Critical states differ from subject-area to subject-area. With security matters for instance, the five permanent United Nations Security Council (UNSC) members are usually critical because enforcement action requires their affirmative vote or abstention.

I consider both public approval and silence to constitute agreement, and only treat public disagreement as evidence of disagreement on a norm interpretation. As Sandholtz $(2008,103)$ aptly observes: "[t]he outcomes of today's disputes help to shape the context, and the pool of precedents, for later cycles." Thus states who disagree with a norm frame and claim have an incentive to publicly signal disapproval to quell a precedent that may produce unwanted obligations: silence signals tacit approval. ${ }^{3}$ Conversely, states who seek to reinterpret a norm require public approval (or at least silence) to create a precedent. Hence, I focus on public debates between states over what norm frame applies to a given situation and what claim to action follows. I will discuss the four different outcomes of norm contestation and their implications in turn.

\section{Norm Clarification (agreement on frame and claim)}

When we see widespread agreement on a frame and claim, the meaning of norms becomes clearer. The different understandings of how to interpret a situation and what to do make way for consensus. Hart $(1994,123)$ described the incompleteness of norms by distinguishing between a "core of certainty" and a "penumbra of doubt". When states agree on what frame and claim apply in a previously disputed situation, the penumbra of doubt becomes smaller and the norm clearer. Norm clarification occurs when others accept, reject or synthesize a frame-claim combination.

Acceptance of an interpretation occurs when there is widespread agreement that the frame-claim combination an actor proposes applies. For instance, Article 51 of the UN Charter states that the right to self-defense applies when "an armed attack occurs against a Member of the United

\footnotetext{
${ }^{3}$ Legally, states can only avoid international customary law obligations by voicing their disapproval from the start (persistent objection). Silence is interpreted as approval. See Thirlway (2008), 103.
} 
Nations". According to the Nicaragua case, invoking this right requires active and significant state involvement in the armed attack. The United States (US) sought to lower this bar by citing selfdefense (frame) to justify military strikes in response to terrorist attacks - such as the strikes against Libya in 1986 (claim) and against Afghanistan and Sudan in 1998 (claim). Several critical states contested these interpretations: in 1986, Spain and France even denied the use of their airspace, forcing a costlier flying route (Byers 2003, 178). These contestations subsided in the aftermath of 9/11. Critical states, and most other states, openly (or at least tacitly) approved the US's norm frame of 'self-defense against state-sponsored terrorism' and its claim to intervene in Afghanistan (Cassese 2001, 996-997; Johnstone 2011, 84). The widespread support led to norm clarification.

Rejection of an interpretation occurs when we see widespread agreement that the frame-claim combination an actor proposes does not apply. When Cyclone Nargis hit Burma, French Foreign Minister Bernard Kouchner asked the UN Security Council to cite R2P (frame) to forgo Burmese consent and deliver emergency relief (claim). Others overwhelmingly dismissed the interpretation that R2P applies to natural disasters (Badescu and Weiss 2010, 362-363), clarifying the scope of R2P. Another example is the Bush administration's repeated claim that it did not torture terror suspects (Forsythe 2007, 66). The administration attempted to justify these claims by reinterpreting legal frames related to the prohibition of torture such as the torture definition, the Geneva Conventions and the prohibition of extra-ordinary rendition (Forsythe 2007, 65-76). As Keating (2014) illustrates, the Bush administration was able to hide these practices, and the memoranda that put forth these interpretations, for several years. Once they became public in 2004-2005, domestic and international resistance started to form. As a result, the administration withdrew the contested legal memos. Both 2008 presidential candidates pledged to end Bush's practices and interpretations: a pledge mostly fulfilled by Barack Obama once in office.

Synthesis occurs when actors reach a compromise between their contrary norm interpretations. This synthesis can be a combination of their different frames and claims or an entirely new frame and claim that all parties can agree to: neither contestant's interpretation prevails, but a compromise is found. The so-called 'Turbot 'War' serves as example. Depleting fish stocks prompted Canada to implement conservation measures within its Exclusive Economic Zone (EEZ). Foreign vessels continued to fish turbot intensively on the Grand Banks right outside of the EEZ, where according to the United Nations Convention on the Law of the Sea (UNCLOS), the freedom of the high seas generally applies. Contesting the freedom of the high seas, Canada 
banned Spanish and Portuguese vessels from fishing turbot on the Grand Banks and in 1995 seized the Spanish trawler Estai, using gunfire (Song 1997, 278). Contestation ensued over whether the principle of 'freedom of the high seas' trumps 'sustainable fisheries' (frames), as both are embedded in UNCLOS, and over what nets, quotas and possible fines (claims) could apply (Song 1997, 282-85). Eventually, Canada and the European Union reached a compromise: they introduced enforcement measures such as observers and satellite tracking devices, and joint quota to improve sustainability. At the same time, Canada repealed its controversial law allowing the arrest of Spanish and Portuguese vessels, dropped criminal charges against the Estai's owners and returned the bond of Can $\$ 500,000$ to them, affirming the freedom of the high seas (Song 1997, 285-86).

Wiener (2014, 58-62) argues that at best, contestation over application closes a legitimacy gap between abstract moral claims of fundamental norms such as 'sustainable fisheries' and their practical enactment. Other scholars have started to identify criteria for when contestation strengthens or weakens norms, and frequently cite Deitelhoff and Zimmermann's (2013) working paper (Bloomfield 2016, 318-19; Niemann and Schillinger 2017, 36; Wiener 2014, 34-35). I adopt their $(2013,14)$ main criterion for strengthening and weakening: namely whether the sense of shared obligation towards a norm is questioned. I argue that application can strengthen or weaken normative commitment along two dimensions: scope and precision. Narrowing the scope of a norm weakens it, as Panke and Petersohn $(2016,4)$ observe because it reduces the number of situations when states share a commitment to the norm. For example, international agreement that R2P does not apply to situations of national disaster narrowed its scope, and extended the scope of the competing sovereignty norm. Deitelhoff and Zimmermann $(2013,9)$ and Badescu and Weiss $(2010,367-69)$ only focus on how the increased precision rendered R2P more acceptable. They miss that this narrowing weakened R2P vis-à-vis sovereignty. Conversely, norm clarification (frame and claim agreement) strengthens the contested norm when it expands a norm's scope or prevents its narrowing. We saw the former with the agreement to expand the right to self-defense to cases of state-sponsored terrorism, and the latter with the rejection of the United States' attempt to narrow the prohibition of torture.

Norm clarification can strengthen or weaken norms vis-à-vis other norms. However, it always increases their precision by clarifying their regulatory ambit. Precision makes legal rules a better reference point for coordination (Abbott et al. 2000, 413) and reduces ambiguity, which can enhance the prospects for compliance (Chayes and Chayes 1993, 188-93). By setting a clearer 
standard, norm clarification makes what counts as 'inappropriate' behavior more obvious and costly, and thus makes cooperation in similar contexts easier. This renders norm clarification a relatively stable outcome. The more precise a norm, and the more situations it was consensually applied to, the more difficult it becomes to engage in reframing and to escape prior commitments (Sandholtz 2008, 109). Hence, precision increases the norm's ability to regulate state behavior.

However, increased precision strengthens some norms more than others. Norm clarification may hinder diffusion across different implementation levels: the more precise the content of a norm, the less room it leaves for the sort of local reinvention or translation that can enable diffusion (Krook and True 2012, 123; Zimmermann 2017, 783). Thus, precision may strengthen norms that the same actors implement at the same (international) level more universally than those that different actors implement at different levels.

Norm clarification also affects reputation. Engaging in contested practices leads to reputational costs and thus negatively affects cooperation and social standing (Johnstone 2011, 210-11; Schimmelfennig 2001,64$)$. The rejection of a frame and claim can damage the reputation of the state whose interpretation others resist. Rejection can even pressure powerful states to drop their interpretation, as the Bush administration's contestation of the torture prohibition illustrates. Brooks and Wohlforth $(2005,518)$ argue that powerful states can shoulder near-term costs of practices and interpretations that many other actors consider illegal better than others. However, the above example shows that they cannot do so indefinitely. By contrast, social acceptance of a frame and a claim or synthesis prevent reputational costs. The social consensus converts a hitherto inappropriate interpretation into an appropriate one.

In sum, agreement on a frame and claim constructs a clearer reference point. Such norm clarification structures future debate by making 'entrapment' with the international community's clarified normative expectations more likely (Bower 2015, 339; Schimmelfennig 2001, 65).

\section{Norm Impasse (disagreement on frame and claim)}

Norm impasse is the opposite of norm clarification. Here, critical states continue to disagree about whether the scope of a normative frame should be extended or curtailed (for example, whether 'state-sponsored terrorism' can trigger 'self-defense'), or about which normative frame applies (for instance, 'freedom of the high seas' vs. 'sustainable fisheries'). They also differ on what the correct 
claim is (for example, permissible fishing). When norm contestation reaches an impasse, the penumbra of doubt persists.

Persistent disagreement on a frame and claim leads to normative uncertainty about what norm applies and what to do. This impasse is unsatisfactory for those involved, no matter whether different values or interests provoke contestation. Norm entrepreneurs who are convinced of their interpretation's appropriateness will continue trying to persuade critical states (Finnemore and Sikkink 1998, 896-99). 'Interest actors' will also try to gain agreement for their norm interpretation to maximize and cement their preferences (Abbott and Snidal 2002, S145). However, actors who publicly uphold norm interpretations that the relevant audiences find unconvincing encounter social and material costs: their social standing and opportunities for cooperation suffer (Johnstone 2011, 210-11; Krebs and Jackson 2007, 44-47; Schimmelfennig 2001, 64). For example, when Crimeans voted to secede and join Russia in 2014, Russian President Putin and Crimean authorities argued that the referendum was in line with "the well-known Kosovo precedent" (Putin 2014) and the right to self-determination of Crimeans. Conversely, the White House (2014) stated that "Ukraine's sovereignty and territorial integrity must be respected" (frame), claiming that "the referendum in Crimea was a clear violation of Ukrainian constitutions and international law". The European Union, another critical actor in this dispute, largely agreed with the United States' assessment. The dispute over what norm applies and which country Crimea belongs to continues, and has put a strain on the relationship between the parties.

Therefore, when we see persistent disagreement on frames and claims, states face pressures that pull them in different directions. This can render norm impasses very stable or short-lived, depending on whether the benefits of protracted contestation outweigh the (normative, social or material) costs.

Abbott and Snidal (2002, S147-S150) argue that interest actors who do not promote a norm interpretation out of moral obligation may be more susceptible to giving up their contestation when offered side payments or coerced. The participation of interest actors in norm contestation can therefore make a norm impasse less stable. However, as Abbott and Snidal (2002, S144) acknowledge, real actors generally have mixed motives and sources of motivation are difficult to disentangle. 
I contend that the degree to which contestants have previously shared commitments is more likely to affect the duration of the norm impasse than the motivations of actors. Scholars often cite a repertoire of shared values, symbols and commitments (referred to by sociologists as in-group identification) as a precondition for reaching common positions on norm interpretations (Johnston 2001, 497; Krebs and Jackson 2007, 56; Schimmelfennig 2001, 62-63). Therefore, it matters whether the opposing sides are culturally dissonant or harmonious and have weak or strong ties with each other (Goddard 2006, 45-47): when in-group members disagree on a frame and claim, their close relationship is likely to render norm impasses unsustainable. This may explain the quick resolution of the Turbot War, where the contestants, Canada and Spain, had manifold cultural ties. However, when in-group and out-group members disagree on what frame applies and what claim follows, a norm impasse is harder to break: social and material costs are lower, and there are fewer cultural ties to aid resolution. This dynamic may explain why contestation over Crimea persists.

Other scholars are more confident that international legal norms (as opposed to moral or political norms) constitute globally shared standards that can overcome in- and out-group divisions (Bower 2015, 339; Johnstone 2011, 21-27; Sandholtz 2008, 106-10). The quality of the legal arguments then determines whether an impasse will persist. For instance, the more often actors consensually applied a norm in similar situations (Sandholtz 2008, 109) and the more precise the norm is (Bower 2015, 346), the more apparent it becomes when legal arguments are misguided and inconsistent. This renders advancing different frames and claims costly in reputational terms and a norm impasse unsustainable. Vague norms and less clear-cut precedents have the opposite effect.

In sum, the duration of a norm impasse depends on the degree to which actors have previously shared commitments. We may locate these shared commitments in culture, relationships, or legality. A norm impasse that persists for a long time prevents the setting of a clear precedent, weakening the contested norms because it reduces normative certainty in similar situations. However, this contestation outcome does not necessarily signal impending norm death. When a norm impasse revolves primarily around the facts of the case (grounds), the contested norm commands a significant amount of respect. For instance, in response to the 2017 chemical weapons attack in Syria, the United States launched missile strikes on Syria. President Donald Trump justified this response by saying that " $[\mathrm{t}]$ there can be no dispute that Syria used banned chemical weapons, violated its obligations under the Chemical Weapons Convention" (BBC News 
2017a). NATO and EU countries and officials agreed that the use of chemical weapons was unacceptable and "must be answered" (BBC News 2017b). Russia and Syria criticized the strikes but did not deny the applicability or validity of the taboo to use chemical weapons. Instead, Russia talked about a "complete disregard for factual information" (The Kremlin 2017). Russian President Vladimir Putin questioned that the Syrian government had launched this attack and attributed it to the rebels (The Kremlin 2017). One year later, he questioned whether it had even occurred (The Kremlin 2018). The criticism of the grounds allowed Putin to frame the US strikes "as an act of aggression against a sovereign state delivered in violation of international law" (The Kremlin 2017). When history repeated itself a year later, the dividing lines were similar (The Kremlin 2018; The White House 2018). Hence, Russia and the United States invoked different frames (sovereignty vs. chemical weapons ban) and claims (illegitimate vs. legitimate missile strikes). However, Russia's criticism of the grounds rather than of the frame signals that the taboo of chemical weapons use is a strong norm that both sides agree to in principle, but disagree about when and how to apply. Different views about the relative importance of the chemical weapons ban and sovereignty, rather than about their validity, characterize the norm impasse. By contrast, direct criticism of the frame, for example of the chemical weapons taboo, indicates weak feelings of obligation.

Norm Recognition (frame agreement, claim disagreement)

Norm recognition occurs when we see widespread agreement on the norm frame but disagreement on the claim. It implies a partial resolution of norm contestation. Frames categorize events and help actors to make sense of the world (Entman 1993, 52; Goffman 1974, 21; Snow et al. 1986, 464). Psychologists see categorization as a vital cognitive process: we have a desire for coherent, structured knowledge and need to categorize information to ascertain how to interact with the world (Billig 1987, 122). Widespread social agreement on a specific norm frame therefore helps to interpret an event and narrows the range of acceptable responses (Entman 1993, 54; Lenz 2018, 44; Zimmermann 2017, 776). The sense of normative commitment that is attached to norm frames (as opposed to policy frames) renders some claims illegitimate and socially unsustainable. Norm recognition blocks some argumentative paths and thereby increases normative certainty compared to a norm impasse, where the frame disagreement allows the advancement of a greater range of claims. 
Thus, agreement on a norm frame is consequential. It can back states into a corner and force them to accept claims they hitherto considered unacceptable. Bower $(2015,351-55)$ illustrates this with the debate over the UNSC mandate for the UN peacekeeping mission in Bosnia and Herzegovina (UNMIBH). He describes how the US sought to obtain immunity for peacekeepers and thus a global exemption for its soldiers from International Criminal Court (ICC) jurisdiction. As part of its argument, the United States cited Article 98 of the Rome Statute, which exempts third states from the ICC's jurisdiction. However, other Council members invoked Article 16 of the Rome Statute as a frame, claiming that granting immunity is only possible on a case-by-case basis for one year and requires UNSC agreement. The US then recognized the Article 16 frame, but claimed that it covers an automatic annual renewal of immunity unless the Security Council decides otherwise. Key Security Council members rejected this claim as contradicting the Article 16 frame. They drew on its negotiation history to suggest that Article 16 was not intended to authorize the Security Council to grant permanent immunity. When critical actors argued that the US's claim did not fall under the Article 16 frame, the US could not negate the applicability of the frame anymore as it had already recognized it. This earlier recognition forced the United States to accept the claim of a more modest one-year exemption in Resolution 1422. Agreement on a norm frame narrows down the range of claims that actors can legitimately advance. Thus, when critical states consider claims as contradicting the proposed frame, norm recognition may be a via media towards norm clarification and a transitory outcome.

However, when the claim disagreement does not blatantly contradict the prior history of the frame, norm recognition is a relatively stable outcome. The contestation over the Kadi case (ongoing since 2002) illustrates this (Morse and Keohane 2014, 395-98). The UNSC agreed, after some contestation with the European Court of Justice (ECJ), to grant blacklisted terror suspects some due process rights (frame) and thus an avenue for removal from the 1267 sanctions list. The two institutions still differ on what this avenue should look like (claim): an independent Ombudsperson, favored by the Security Council, or an external court, favored by the ECJ. Since neither of these claims blatantly contradict the due process frame, norm recognition has been stable and reputational costs limited. The classification of an event into a normative category reduces normative uncertainty. It limits the range of actions that actors can legitimately pursue and publicly affirms the commitment to the norm frame. I contend that when the actions fall within the permissible range this makes norm recognition socially sustainable, and a relatively stable outcome. 
Norm recognition strengthens a norm when a norm impasse precedes it. Consensus around a norm frame expands the scope of that norm and increases normative certainty by narrowing the range of claims that actors can credibly advance. However, norm recognition does not increase precision as much as norm clarification, which sets a clearer precedent due to the claim agreement.

Hence, when preceded by norm clarification, norm recognition can weaken a norm by reducing its clarity. For example, after Iraq's invasion of Kuwait, UNSC members largely agreed that Saddam Hussein's non-cooperation on weapons of mass destruction (WMD) constituted a "threat to the peace" within the meaning of Article 39 of the UN Charter, requiring a response under Chapter VII (frame): the imposition of sanctions (claim). The frame agreement persisted around the 2003 Iraq invasion. However, the permanent Security Council members then disagreed on the resulting claim: some argued that the threat emanating from Saddam Hussein's WMD program required military intervention; others considered sanctions and diplomacy adequate (Johnstone 2011, 126). This claim disagreement weakened normative certainty of what reaction to a perceived threat to the peace is appropriate. However, the agreement on the 'threat to the peace' frame reduced uncertainty more than a norm impasse by ruling out options such as inaction.

Norm Neglect (frame disagreement, claim agreement)

Norm neglect occurs when we see widespread agreement on the claim despite of persistent disagreement on the frame. This scenario is best described as norm neglect since normative uncertainty persists despite tangible action. Krebs and Jackson $(2007,44)$ argue that the outcomes that involve acceptance of the claim are "(at least temporary) terminuses" that are "relatively stable outcomes in the short and medium run." I contend that when it comes to norm contestation, frame agreement provides more stability because it signals normative commitment and narrows the range of claims that states consider appropriate. Since claim agreement leads to joint actions, it is more visible than words. Hence, norm neglect is likely to require explanations from the action's supporters when a similar situation arises in the future. This makes norm neglect an unstable outcome: it produces a temporary and partial consensus that will eventually result in either a norm impasse or norm clarification. 
When actors agree to a claim without accepting a frame, "acculturation" might be at work: social pressure leads to "outward conformity with a social convention without private acceptance" (Goodman and Jinks 2004, 643). Unlike frame agreement, claim agreement alongside frame disagreement does not signal normative commitment: it only signals outward conformity. Thus, I contend that states can portray their acceptance of a claim that does not correspond to their normative understandings as an exception. Actors can refer to the particularities of the claim agreement to advance a different frame in the future and to escape entrapment. For instance, permanent UNSC members have long differed over whether R2P or sovereignty prevails when states engage in mass atrocities, but they did agree to establish a no-fly zone over Libya in 2011. Instead of accepting the R2P frame, China reaffirmed its commitment to sovereignty and referred to the special circumstances in Libya, and both Russia and China cited regional organizations' request for, and endorsement of, the no-fly zone (frame) (United Nations Security Council 2011, 8-11). Hence, Russia and China can refer to the special circumstances surrounding the Libya case to explain why another context is different. Russia resisted UNSC resolutions on Syria by arguing that the toppling of the Libyan regime went beyond the claim (no-fly zone) it had agreed to (Johnstone 2015, 243). Hence, the possibility of referring to the circumstances surrounding the claim agreement can make norm neglect a temporary concession in a longstanding norm impasse.

On the other hand, claim agreement may be a step towards norm clarification. In Risse and Sikkink's $(1999,25)$ spiral model, strategic tactical concessions of repressive governments such as the release of prisoners can generate momentum. The concessions empower the opposition and create more space for socialization efforts. The government's agreement with the opposition's claim, despite frame disagreement, may thus legitimate the opposition's activities and make their efforts to gain acceptance for their frame more effective. Constructivists find that socialization can trigger norm compliance (Checkel 2005; Finnemore and Sikkink 1998; Johnston 2001), or in this case, norm clarification. Socialization works by persuasion and social influence: information, arguments and cognitive cues that alter behavior and beliefs, and praise and rewards for ruleconforming behavior (Johnston 2001, 496-502). By agreeing to a claim, actors may receive social recognition and new information that convinces them to accept a different norm frame. An example is China's dispute with the World Health Organization (WHO) on how to manage the severe acute respiratory syndrome (SARS) outbreak. China refused to accept health measures and travel warnings that the WHO suggested (claim). Hence, China reaffirmed its commitment to sovereignty and contested the WHO's authority in managing health emergencies (frames). Under 
international pressure, China eventually made concessions and accepted the WHO's claims, which helped to contain the SARS crisis. Agreeing with the WHO's claims provided China with new information and persuaded it to more actively engage in global health governance, even leading China to accept a strengthening of global health norms and of the WHO's authority (frame) (Huang 2010; Kreuder-Sonnen 2016, 213-41).

Hence, while claim acceptance can be a temporary concession, it can also trigger socialization processes that lead to norm clarification. It is a task for future research to examine more systematically when norm neglect generates norm clarification or norm impasse.

\section{An Extended Illustration of the Dynamics of Norm Contestation}

I now discuss one of the aforementioned examples in greater detail to show how this typology helps scholars to analyze the dynamics of norm contestation: the Bush administration's contestation of the prohibition of torture and mistreatment. I base this analysis on Vincent Keating's (2014) dataset of newspaper and television coverage ${ }^{4}$ I added primary sources such as legal memoranda and press briefings, and coded the reported statements to identify the frames and claims and how officials legitimated them.

States do not always want to set a precedent. Sometimes "organized hypocrisy" (Krasner 1999, 68) or "double standards" (Koh 2003, 1486-87) characterize the norm application. Such exceptionalism occurs when a state implements a claim that others would consider to contradict the frame. When the norm is well-established, we would expect the state to be secretive and to deny its behavior when questioned in order to avoid reputational costs. In this vein, the US's contestation of the prohibition of torture largely remained below the radar between 2001 and 2003. In 2002 pictures of masked, shackled and blindfolded prisoners in transit to Guantanamo led to allegations of mistreatment and torture. ${ }^{5}$ Secretary of Defense Donald Rumsfeld's remarks that while the United States "for the most part" complied with the Geneva Conventions, it did not have to fully comply because the detainees were "unlawful combatants" without "any rights under the Geneva Convention" fuelled contestation (The Washington Post 2002). Those who spoke out -

\footnotetext{
${ }^{4}$ I thank Vincent Keating for sharing his dataset with me. Source: Nexis, All English Language News. Search terms: ("United States" or "America" or "Bush") w/p "torture". Timeframe: September 11, 2001 20 January 2009.

5 See Spokespersons for Amnesty International, The Medical Foundation for the Care of Victims of Torture, and British members of parliament (Lowther and Rosenberg 2002).
} 
Germany, the Netherlands and Britain - only rejected the frame, insisting on prisoner-of-war status (Buzbee 2002). In-group members primarily justified their agreement on the claim of lawful treatment based on the United States' liberal identity and their belief in American assurances. ${ }^{6}$ Later reports of prisoner deaths and mistreatment mainly drew criticism from non-governmental organizations (NGOs) and the media. The US often answered these charges by stating its commitment to (inter)national law and the just character of the American legal system. ${ }^{7}$ Hence, we had a situation of norm neglect: widespread agreement or silence from states on the claim that the US did not mistreat or torture prisoners, alongside frame disagreement. The justificatory discourse shows that American credibility as norm supporter facilitated the claim agreement. The "cultural match" (Busby 2007, 254) between the contested norm and the US's liberal identity made the identity-based legitimation persuasive.

Most US practices become public between 2004-2005, prompting criticism from domestic politicians and in-group members. As a result, the United States withdrew some frames and claims such as the Bybee memorandum, which sought to lower the threshold for torture, and closed Central Intelligence Agency (CIA) black sites in Eastern Europe. When rejecting torture claims, George W. Bush continued to refer to the US's liberal image. Justifications such as "torture is not a part of our soul and our being" (Bush 2004) reflect this. Many European countries remained supportive (Keating 2014, 11-12). Their support lowered reputational costs. German foreign minister Frank-Walter Steinmeier stated that his American counterpart Condoleezza Rice "has reiterated that in the US international obligations are not interpreted differently than in Europe" (The Irish Times 2005). Beyond journalists, NGOs and international organizations (IOs), out-group members with poor human rights records criticized the United States. They accused the United States of hypocrisy regarding torture (China Daily 2005; Ministry of Foreign Affairs of Cuba 2005). This period therefore mainly consists of a norm impasse: in-group members generally supported the 'no torture'-claim and the frame of rightful interpretation of the torture prohibition, ${ }^{8}$ while out-group members rejected the 'no-torture' claim and the frame of lawcompliance.

\footnotetext{
${ }^{6}$ See statements by British Spokesperson (Gardiner 2002); German Foreign Minister Joschka Fischer (BBC Monitoring Europe 2002); Australian Spokesperson (BBC Monitoring Asia Pacific 2003).

7 See statements by White House Press Secretary Ari Fleischer (The White House 2002) and George W. Bush (CNN 2003).

${ }^{8}$ See, for example, German Chancellor Angela Merkel's statement (The Australian 2005).
} 
From 2005 onwards, we see a decline in references to the US's identity and a rise in references to the need for protection from terrorism, ${ }^{9}$ and soon after, a shift in the Bush administration's strategy, from denial to open reinterpretation attempts. First, inquiries from IOs and NGOs concluded that US practices in Guantanamo and elsewhere constituted torture, as stipulated in the Convention Against Torture (CAT). ${ }^{10}$ US officials rejected the frame and claim, arguing that CAT does not apply in situations of armed conflict (Schofield 2006), and reminded the world of the dangerous terrorists in Guantanamo (Angle, Garrett, Baier and Rosen 2006). Second, while continuing to deny the torture claim, George W. Bush (2006) started to portray an "alternative set of procedures" - later dubbed enhanced interrogation techniques - as effective in combating terrorism. US authorities acknowledged using waterboarding between 2002 and 2003. They said that "the programs have been reviewed, and the Department of Justice has determined them to be legal" (Fratto 2008) (frame and claim), and that waterboarding was used because further terrorist attacks seemed imminent then. ${ }^{11}$ Such interest-based legitimation shows that the Bush administration decided to openly reinterpret the torture prohibition in the context of terrorism. Legitimation based on beneficial outputs, such as terror prevention, requires less shared values and so may facilitate agreement from both in- and out-groups (Jones 2009, 1086).

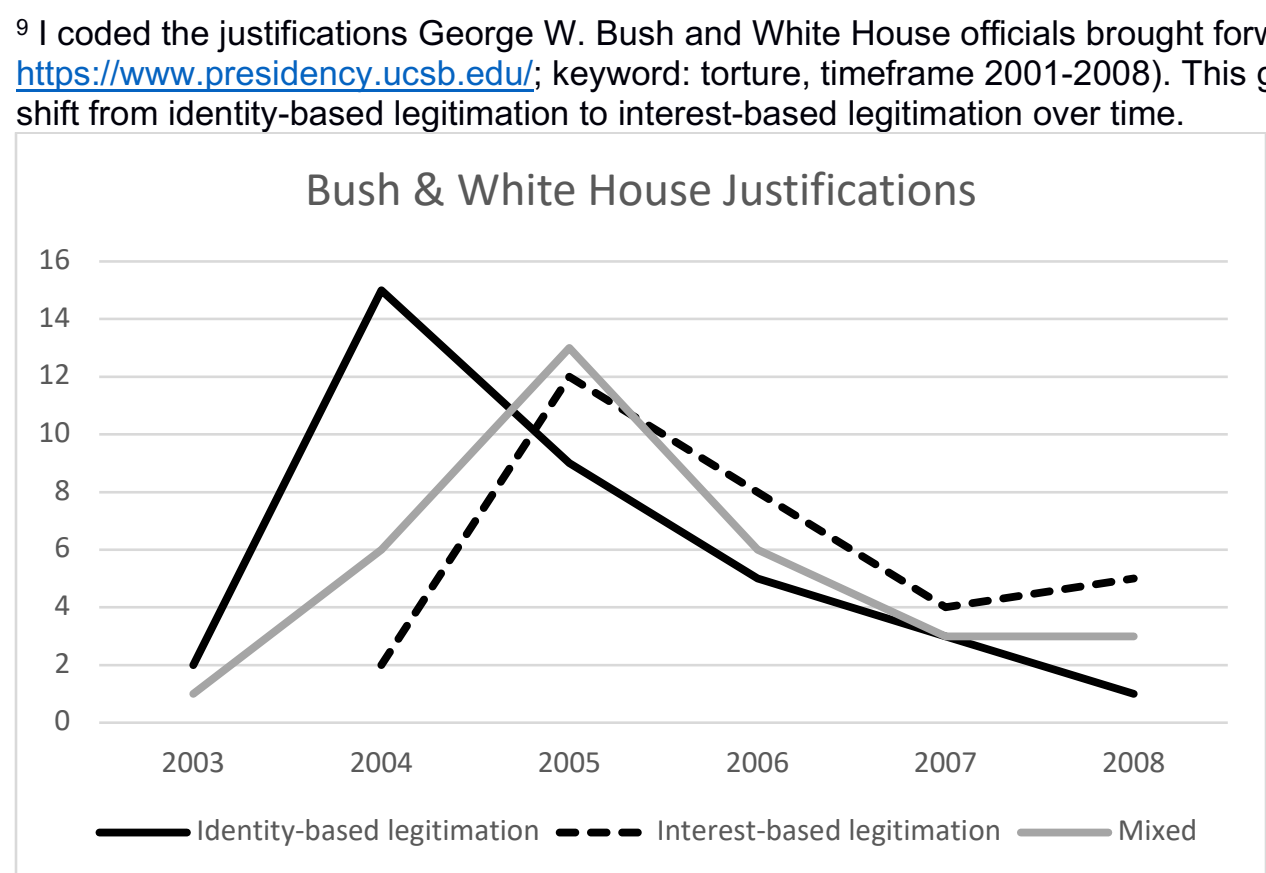

10 See, for example, United Nations Committee Against Torture (2006).

11 See statement by CIA Director, Michael V. Hayden (Mikkelsen 2008). 
This legitimation strategy was unsuccessful. Critical actors whose support was necessary favored a narrower interpretation. Domestically, both US presidential candidates in 2008 condemned waterboarding and affirmed their belief in the prohibition of torture (Fisher 2008), and Congress passed a bill, trying to stop enhanced interrogations (Herszenhorn 2008). In-group opposition further intensified: Spain stopped extraditions; Dutch soldiers were instructed not to hand over Afghan captives to the United States because of fears of abuse (The Gazette 2008), a high-level British parliamentary committee criticized CIA black sites and prisoner mistreatment (Bonner and Perlez 2007). A senior British intelligence official told the parliamentary committee that use of torture "never crossed my mind" because "we are talking about the Americans, our closest ally. This now, with hindsight, may look naïve, but all I can say is that is what we thought at the time" (Bonner and Perlez 2007). In-group members initially found the identity-based legitimation strategy persuasive but the revelations and reinterpretation attempts damaged the US's image. The social pressure did not go by unnoticed. One of Obama's first acts was to repudiate the Bush administration's legal opinions on torture and most contested practices (Executive Order 13491). The rejection of the Bush administration's interpretations generated norm clarification.

\section{Conclusions}

This note developed an outcome typology that clarifies the way that actors can agree or disagree over norms. Some may doubt the relevance of mapping norm contestation outcomes. Niemann and Schillinger (2017) regard contestation as never-ending because they question whether norms can reflect shared understandings. However, even if states never share the exact same understanding of norms in the abstract, there can be different degrees of consensus on their application to a specific situation. Application shapes the norm and make its meaning more or less shared. Differentiating between four outcomes - in norm clarification, norm recognition, norm neglect, or norm impasse-allows us to better grasp the 'dual quality' of norms, and thus the different ways in which contestation shapes norms and structures behavior and debate.

I close with three additional thoughts about how this typology helps us to better understand important aspects of norm contestation. 
First, by coding the justifications, frames and claims that critical actors advance, scholars can uncover legitimation strategies and mechanisms through which norm contestation, and sometimes norm clarification, unfolds. This typology therefore facilitates theoretically grounded empirical research into norm contestation dynamics. Such research could fill a gap in the literature since norm contestation research is often theoretical and self-reflective (Niemann and Schillinger 2017; Wiener 2014; Wolff and Zimmermann 2016).

Second, this typology helps scholars to identify further pathways that lead to (dis)agreement on frames and/or claims. Scholars can use it to find scope conditions when their mechanisms limit contestation and opportunism. For instance, drawing on Habermas, some scholars argue that 'better', legally more correct, arguments carry more weight in norm contestation (Johnstone 2011, 27; Risse 2000, 20). However, strong legal arguments often fail to produce norm clarification on their own, as the debate over the prohibition of torture showed. Habermasian scholars of deliberation could use this typology to explore how variations in negotiating settings or in the characteristics of the contested norms produce different sorts of outcomes. Other scholars find that the configuration of relationships between contestants explains the resolution or persistence of contestation (Goddard 2006, 40; Krebs and Jackson 2007, 55-56).

Studying in-group/out-group dynamics could shed light on what makes different norm contestation outcomes likely, and help to refine reputational mechanisms. Practice scholars could also use this typology to refine their approach. Adler-Nissen and Pouliot $(2014,891)$ highlight the contribution of competent negotiating skills to the agreement on the no-fly zone over Libya. Practice scholars could investigate why practical competence could generate claim agreement, but not frame agreement, and what types of competence, or lack thereof, generate the four outcomes. Moreover, the typology should also help us to analyze disagreements arising from the implementation of norms between settings, as local, regional, and international actors may disagree about norm frames, claims, or both.

Lastly, scholars of international law and international relations work closely together in the study of norms in world affairs. However, the former use insights from the latter far more than the other way around (Sandholtz 2008, 102). As scholars of international law are experts at identifying the frames and claims states advance in disputes, this typology underscores how their insights can inform research in the field of International Relations. 


\section{Supplementary Information}

Official norm interpretations that are not easily accessible online as well as my coding scheme for the extended illustration are available at http://anettestimmer.com/data, https://dataverse.harvard.edu/dataverse/anettestimmer and the International Studies Quarterly data archive.

\section{References}

Abbott, Kenneth W., Robert O. Keohane, Andrew Moravcsik, Anne-Marie Slaughter, and Duncan Snidal. 2000. "The Concept of Legalization.” International Organization 54 (3): 401-19.

Abbott, Kenneth W., and Duncan Snidal. 2002. "Values and Interests: International Legalization in the Fight against Corruption." The Journal of Legal Studies 31 (S1): S141-S178.

Acharya, Amitav. 2004. "How Ideas Spread: Whose Norms Matter? Norm Localization and Institutional Change in Asian Regionalism." International Organization 58 (2): 239-75.

Acharya, Amitav. 2011. "Norm Subsidiarity and Regional Orders: Sovereignty, Regionalism, and Rule-Making in the Third World." International Studies Quarterly 55 (1): 95-123.

Acharya, Amitav. 2013. "The R2P and Norm Diffusion: Towards a Framework of Norm Circulation." Global Responsibility to Protect 5: 466-79.

Adler-Nissen, Rebecca, and Vincent Pouliot. 2014. "Power in Practice: Negotiating the International Intervention in Libya." European Journal of International Relations 20 (4): 889-911.

Angle, Jim, Major Garrett, Bret Baier and James Rosen. 2006. "Fox Special Report with Brit Hume." Fox News Network, February 17. Nexis, All English Language News.

Badescu, Cristina G., and Thomas G. Weiss. 2010. "Misrepresenting R2P and Advancing Norms: An Alternative Spiral?" International Studies Perspectives 11 (4): 354-74.

Barnett, Michael, and Raymond Duvall. 2005. "Power in International Politics." International Organization 59 (1): 39-75.

BBC Monitoring Asia Pacific. 2003. "Australia says Guantanamo detainees "treated humanely". $B B C$ Worldwide Monitoring, October 8. Nexis, All English Language News.

BBC Monitoring Europe. 2002. "Foreign minister says Germany a human rights advocate." BBC Worldwide Monitoring, March 14. Nexis, All English Language News.

BBC News. 2017a. "President Trump's Syria strike statement in full." BBC US \& Canada, April 7. https://www.bbc.co.uk/news/world-us-canada-39524274.

BBC News 2017b. "Syria war: World reaction to US missile attack." BBC US \& Canada, April 7, 2017. http://www.bbc.co.uk/news/world-us-canada-39526089.

Bederman, David J. 2006. International Law Frameworks. New York, NY: Foundation Press.

Billig, Michael. 1987. Arguing and Thinking: A Rhetorical Approach to Social Psychology. Cambridge, U.K.: Cambridge University Press.

Bloomfield, Alan. 2016. "Norm Antipreneurs and Theorising Resistance to Normative Change." Review of International Studies 42 (2): 310-333.

Bonner, Raymond and Jane Perlez. 2007. "British Report Criticizes U.S. Treatment of Terror Suspects." The New York Times, July 28. https://www.nytimes.com/2007/07/28/world/europe/28rendition.html.

Bower, Adam. 2015. "Arguing with Law: Strategic Legal Argumentation, US Diplomacy, and Debates over the International Criminal Court." Review of International Studies 41 (2): 337-60. 
Brooks, Stephen G., and William C. Wohlforth. 2005. "International Relations Theory and the Case against Unilateralism." Perspectives on Politics 3 (3): 509-524.

Busby, Joshua W. 2007. "Bono Made Jesse Helms Cry: Jubilee 2000, Debt Relief, and Moral Action in International Politics." International Studies Quarterly 51 (2): 247-75.

Bush, George W. 2004. "Remarks Following Discussions With Prime Minister Peter Medgyessey of Hungary and an Exchange with Reporters." The American Presidency Project, June 22. https://www.presidency.ucsb.edu/documents/remarks-followingdiscussions-with-prime-minister-peter-medgyessy-hungary-and-exchange.

Bush, George W. 2006. "Remarks on the War on Terror." The American Presidency Project, September 6. https://www.presidency.ucsb.edu/documents/remarks-the-war-terror.

Buzbee, Sally. 2002. "Rumsfeld Defends Handling of Afghans." Associated Press Online, January 22. Nexis, All English Language News.

Byers, Michael. 2003. "Preemptive Self-Defense: Hegemony, Equality and Strategies of Legal Change." Journal of Political Philosophy 11 (2): 171-90.

Cassese, Antonio. 2001. "Terrorism Is Also Disrupting Some Crucial Legal Categories of International Law." European Journal of International Law 12 (5): 993-1001.

Chayes, Abram and Antonia Handler Chayes. 1993. "On Compliance." International Organization 47 (2): 175-205.

Checkel, Jeffrey T. 2005. "International Institutions and Socialization in Europe: Introduction and Framework." International Organization 59 (4): 801-826.

China Daily. 2005. "Human Rights Record of the US in 2004 (full text)." The Information Office of the State Council of the People's Republic of China, March 3. http://www.chinadaily.com.cn/english/doc/2005-03/03/content 421420.htm.

CNN. 2003. "Diplomatic Trip: President Leaves Australia." CNN Live at Daybreak, October 23. http://edition.cnn.com/TRANSCRIPTS/0310/23/lad.04.html.

Deitelhoff, Nicole, and Lisbeth Zimmermann. 2013. "Things We Lost in the Fire: How Different Types of Contestation Affect the Validity of International Norms." Frankfurt am Main (PRIF Working Papers 18), accessed February 4, 2018, http://nbnresolving.de/urn:nbn:de:0168-ssoar-455201.

Entman, Robert M. 1993. "Framing: Toward Clarification of a Fractured Paradigm." Journal of Communication 43 (4): 51-58.

Epstein, Charlotte. 2008. The Power of Words in International Relations: Birth of an AntiWhaling Discourse. Cambridge, MA: MIT Press.

Epstein, Charlotte. 2013. "Constructivism or the Eternal Return of Universals in International Relations. Why Returning to Language Is Vital to Prolonging the Owl's Flight." European Journal of International Relations 19 (3): 499-519.

Evers, Miles M. 2017. "On Transgression." International Studies Quarterly 61 (4): 786-794.

Executive Order 13491. 2009. "Ensuring Lawful Interrogations." U.S. Government Publishing Office, January 22. https://www.govinfo.gov/content/pkg/CFR-2010-title3-vol1/pdf/CFR2010-title3-vol1-eo13491.pdf.

Finnemore, Martha, and Kathryn Sikkink. 1998. "International Norm Dynamics and Political Change." International Organization 52 (4): 887-917.

Finnemore, Martha, and Stephen J. Toope. 2001. "Alternatives to 'Legalization': Richer Views of Law and Politics." International Organization 55 (3): 743-758.

Fisher, William. 2008. "U.S. Attorney General Michael Mukasey refuses to open a criminal investigation; RIGHTS-US: White House, Justice Won't Renounce Waterboarding." IPS Inter Press Service. February 8. http://www.ipsnews.net/2008/02/rights-us-white-housejustice-wont-renounce-waterboarding/.

Forsythe, David P. 2007. The Politics of Prisoner Abuse. Cambridge, U.K.: Cambridge University Press.

Fratto, Tony. 2008. "Press Briefing by Tony Fratto." The American Presidency Project, February 


\section{6. https://www.presidency.ucsb.edu/documents/press-briefing-tony-fratto-12.}

Gardiner, Beth. 2002. "Guantanamo prisoner photos stir controversy in Britain." Associated Press Worldstream, January 20. Nexis, All English Language News.

Goddard, Stacie E. 2006. "Uncommon Ground: Indivisible Territory and the Politics of Legitimacy." International Organization 60 (1): 35-68.

Goffman, Erving. 1974. Frame Analysis: An Essay on the Organization of Experience. Cambridge, MA: Harvard University Press.

Goodman, Ryan, and Derek Jinks. 2004. "How to Influence States: Socialization and International Human Rights Law." Duke Law Journal 54 (3): 621-703.

Hart, H. L. A. 1994. The Concept of Law. Oxford, U.K.: Oxford University Press.

Herszenhorn, David. 2008. "Bill Curbing Terror Interrogators Is Sent to Bush, Who Has Vowed to Veto It." The New York Times, February 14. https://www.nytimes.com/2008/02/14/washington/14cong.html.

Huang, Yanzhong. 2010. "Pursuing Health as Foreign Policy: The Case of China." Indiana Journal of Global Legal Studies 17 (1): 105-146.

Ikenberry, G. John, and Charles A. Kupchan. 1990. "Socialization and Hegemonic Power." International Organization 44 (3): 283-315.

International Court of Justice. 1986. Case Concerning Military and Paramilitary Activities In and Against Nicaragua (Nicaragua v. United States of America). June 27,

Johnston, Alastair lain. 2001. "Treating International Institutions as Social Environments." International Studies Quarterly 45 (4): 487-515.

Johnstone, Ian. 2011. The Power of Deliberation: International Law, Politics and Organizations. New York, NY: Oxford University Press.

Johnstone, Ian. 2015. "When the Security Council Is Divided: Imprecise Authorizations, Implied Mandates, and the 'Unreasonable Veto.'" In The Oxford Handbook of the Use of Force in International Law, edited by Marc Weller, 227-250. Oxford, U.K.: Oxford University Press.

Jones, Erik. 2009. "Output Legitimacy and the Global Financial Crisis: Perceptions Matter." Journal of Common Market Studies 47 (5): 1085-1105.

Keating, Vincent C. 2014. "Contesting the International Illegitimacy of Torture: The Bush Administration's Failure to Legitimate Its Preferences within International Society." The British Journal of Politics \& International Relations 16 (1): 1-27.

Keck, Margaret E., and Kathryn Sikkink. 1998. Activists Beyond Borders: Advocacy Networks in International Politics. Ithaca, NY: Cornell University Press.

Kelley, Judith G., and Beth A. Simmons. 2015. "Politics by Number: Indicators as Social Pressure in International Relations." American Journal of Political Science 59 (1): 55-70.

Koh, Harold H. "On American Exceptionalism." Stanford Law Review 55 (5): 1479-1527.

Koskenniemi, Martti. 2005. From Apology to Utopia: The Structure of International Legal Argument. Cambridge, U.K.: Cambridge University Press.

Krasner, Stephen D. 1999. Sovereignty: Organized Hypocrisy. Princeton, NJ: Princeton University Press.

Krebs, Ronald R., and Patrick Thaddeus Jackson. 2007. "Twisting Tongues and Twisting Arms: The Power of Political Rhetoric." European Journal of International Relations 13 (1): 3566.

Kreuder-Sonnen, Christian. "Emergency Powers of International Organizations. Between Normalization and Containment." (PhD thesis, Freie Universität Berlin, 2016).

Krook, Mona Lena, and Jacqui True. 2012. "Rethinking the Life Cycles of International Norms: The United Nations and the Global Promotion of Gender Equality." European Journal of International Relations 18 (1): 103-27.

Lenz, Tobias. 2018. "Frame Diffusion and Institutional Choice in Regional Economic Cooperation." International Theory 10 (1): 31-70. 
Lowther, William and Carol Rosenberg. 2002. "Horror of Camp X-Ray; First Pictures show use of sensory deprivation to soften up suspects for interrogation." Mail on Sunday, January 20. Nexis, All English Language News.

McAdam, Doug, Sidney G. Tarrow, and Charles Tilly. 2001. Dynamics of Contention. Cambridge, U.K.: Cambridge University Press.

Mikkelsen, Randall. 2008 "CIA says used waterboarding on three suspects. Reuters, February 6. https://www.reuters.com/article/us-security-usa-waterboardingidUSN0517815120080206.

Mills, Kurt, and Alan Bloomfield. 2018. "African Resistance to the International Criminal Court: Halting the Advance of the Anti-Impunity Norm." Review of International Studies 44 (1): 101-27.

Ministry of Foreign Affairs of Cuba. 2005. "Cuba calls on the United States to stop the torture of prisoners in Guantánamo." Official Web Site, January 19.

http://anterior.cubaminrex.cu/English/Statements/Articulos/StatementsMINREX/2005/0501-19.html.

Morse, Julia C., and Robert O. Keohane. 2014. "Contested Multilateralism." The Review of International Organizations 9 (4): 385-412.

Niemann, Holger, and Henrik Schillinger. 2017. "Contestation 'All the Way down'? The Grammar of Contestation in Norm Research." Review of International Studies 43 (1): 29-49.

Panke, Diana, and Ulrich Petersohn. 2016. "Norm Challenges and Norm Death: The Inexplicable?" Cooperation and Conflict 51 (1): 3-19.

Putin, Vladimir. 2014. "Address by President of the Russian Federation." The Kremlin, March 18. http://en.kremlin.ru/events/president/news/20603.

Risse, Thomas. 2000. “Let's Argue!': Communicative Action in World Politics.” International Organization 54 (1): 1-39.

Risse, Thomas, and Kathryn Sikkink. 1999. "The Socialization of International Human Rights Norms into Domestic Practices: An Introduction." In The Power of Human Rights: International Norms and Domestic Change, edited by Thomas Risse, Stephen C. Ropp, and Kathryn Sikkink, 1-38. Cambridge, U.K.: Cambridge University Press.

Sandholtz, Wayne. 2008. "Dynamics of International Norm Change: Rules against Wartime Plunder." European Journal of International Relations 14 (1): 101-31.

Schimmelfennig, Frank. 2001. "The Community Trap: Liberal Norms, Rhetorical Action, and the Eastern Enlargement of the European Union." International Organization 55 (1): 47-80.

Schimmelfennig, Frank. 2008. The EU, NATO and the Integration of Europe: Rules and Rhetoric. Cambridge, U.K.: Cambridge University Press.

Schofield, Matthew. 2006. "U.S. denies torture allegations; A U.N. panel in Geneva said the U.S. was playing word games over actions in Iraq and elsewhere." The Philadelphia Inquirer, May 6. Nexis, All English Language News.

Schön, Donald A., and Martin Rein. 1994. Frame Reflection: Toward the Resolution of Intractable Policy Controversies. New York, NY: BasicBooks.

Snow, David A., E. Burke Rochford Jr, Steven K. Worden, and Robert D. Benford. 1986. "Frame Alignment Processes, Micromobilization, and Movement Participation." American Sociological Review 51 (4), 464-481.

Song, Yann-Huei. 1997. "The Canada-European union turbot dispute in the northwest Atlantic: An application of the incident approach." Ocean Development \& Law 28 (3), 269-311.

The Australian. 2005. "Rice weathers CIA storm in Germany." The Australian, December 7. Nexis, All English Language News.

The Gazette. 2008. "Torture is ineffective - and also immoral." Editorial, January 20. Nexis, All English Language News. 
The Irish Times. 2005. "Rice tries to reassure Nato on torture." The Irish Times, December 9. https://www.irishtimes.com/news/rice-tries-to-reassure-nato-on-torture-1.1173074.

The Kremlin. 2017. "Comment from the Press Service of the President of Russia." President of Russia News, April 7. http://en.kremlin.ru/events/president/news/54241.

The Kremlin. 2018. "Statement by President of Russia Vladimir Putin." President of Russia News, April 14. http://en.kremlin.ru/events/president/news/57257.

The Washington Post. 2002. "Follow the Geneva Convention". Editorial, January 17. Nexis, All English Language News.

The White House. 2002. "Press Briefing by Ari Fleischer." The White House, January 28. https://georgewbush-whitehouse.archives.gov/news/releases/2002/01/2002012811.html.

The White House. 2014. "Statement by the President on Ukraine." The White House, March 17. https://obamawhitehouse.archives.gov/the-press-office/2014/03/17/statement-presidentukraine.

The White House. 2018. "Statement by President Trump on Syria." The White House, April 13. https://www.whitehouse.gov/briefings-statements/statement-president-trump-syria/.

Thirlway, Hugh. 2008. "The Sources of International Law.” In International Law. 6th edition, edited by Shaw, Malcolm N., 91-117. Cambridge, U.K.: Cambridge University Press.

Toulmin, Stephen. 1958. The Uses of Argument. Cambridge, U.K.: Cambridge University Press.

United Nations Committee Against Torture. 2006. "UN Committee Against Torture: Conclusions and Recommendations, United States of America." July 25, CAT/C/USA/CO/2. https://www.refworld.org/docid/453776c60.html.

United Nations Security Council. 2011. "The situation in Libya." Meeting 6498, March 17, S/PV.6498. http://www.un.org/en/ga/search/view doc.asp?symbol=S/PV.6498.

Van Kersbergen, Kees, and Bertjan Verbeek. 2007. "The Politics of International Norms: Subsidiarity and the Imperfect Competence Regime of the European Union." European Journal of International Relations 13 (2): 217-38.

Wiener, Antje. 2004. "Contested Compliance: Interventions on the Normative Structure of World Politics." European Journal of International Relations 10 (2): 189-234.

Wiener, Antje. 2008. The Invisible Constitution of Politics: Contested Norms and International Encounters. Cambridge, U.K.: Cambridge University Press.

Wiener, Antje. 2014. A Theory of Contestation. New York, NY: Springer.

Wolff, Jonas, and Lisbeth Zimmermann. 2016. "Between Banyans and Battle Scenes: Liberal Norms, Contestation, and the Limits of Critique." Review of International Studies 42 (3): 513-34.

Zimmermann, Lisbeth. 2017. "More for Less: The Interactive Translation of Global Norms in Postconflict Guatemala." International Studies Quarterly 61 (4): 774-85.

Zwingel, Susanne. 2012. "How Do Norms Travel? Theorizing International Women's Rights in Transnational Perspective." International Studies Quarterly 56 (1): 115-29. 